\title{
加熱改質フライアッシュを用いたセメントペーストの流動性に及ぼす 化学混和剂の作用に関する研究
}

\author{
石田征男 ${ }^{* 1}$ 佐藤嘉昭 ${ }^{* 2}$ 大谷俊浩 ${ }^{* 3}$ 上田賢司 ${ }^{* 2}$
}

\begin{abstract}
*1 大分大学 大学院工学研究科環境工学専攻 (T870-1192 大分県大分市旦野原 700) 太平洋セメント株式会社 中央研究所

*2 株式会社ゼロテク) ( $870-0027$ 大分県大分市末広町 1-5-16 ユナイテッド末広ビル)

*3 大分大学 理工学部創生工学科建築学コース (
\end{abstract}

\begin{abstract}
要旨：セメントおよび品質が異なる 2 種類の加熱改質フライアッシュ(M-FA)を用いた高流動コンクリー トに関する研究の一環として、これらの材料とポリカルボン酸系高性能 $\mathrm{AE}$ 減水剂(SP)を使用したセメ ントペーストの流動性について粉体の物理的性状、SP 添加の効果拈よびこれらの評価指標について検討 した。その結果、セメントペーストの流動性は、使用した粉体材料の物性だけでなく、SP 添加にともな う電気的反発力の変化の影響を受ける可能性があり、余剩水膜厚粒径比捛よび SP 添加によるゼー夕電位 の変動比を用いた指標により評価できる可能性があることを示した。
\end{abstract}

キーワード : 改質フライアッシュ、比表面積、高性能 $\mathrm{AE}$ 減水剤、セメントペースト、流動性、余剩水膜厚、 吸着量、ゼー夕電位

\section{1.はじめに}

近年、環境負荷の軽減、構造物の長寿命化などの観点 から、加熱改質装置を用いてフライアッシュの強熱減 量を 1 \%以下に低減した加熱改質フライアッシュ(以下 M-FA）が開発、実用化された ${ }^{1)}$ 。M-FA の製造に用い る加熱改質装置は風力粉砕・分級システムを備えており、 このシステムを使用することで JIS A 6201 に規定され るI 種、II 種拉よび IV 種の品質に適合する M-FA を 得ることができる。このことにより、コンクリートの用 途や要求性能に応じた M-FA 種類の選定や粉体粒度の 調整などが可能となるため、フライアッシュの特長を活 かした合理的利用の実現が可能となると考えられる。

筆者らは、M-FAの利点を活かした用途として高流 動コンクリートへの適用を検討中である。検討では、 $\mathrm{M}-\mathrm{FA}$ の物理・化学的特性、粉体の構成、コンクリー トの調合などの条件がコンクリートの各種性状に及ぼす 影響を明らかにすることで、M-FA を用いた高流動コ ンクリート(以下 M-FA 高流動コンクリート)の材料構 成設計技術の確立を目指している。

これまでに、M-FA 高流動コンクリートの流動性を 理論的に検討する目的で、異なる数種類の混合粉体を用 いてセメントペーストの流動性試験を行い、セメント ペーストの流動性と粉体材料の種類掞よび調合との関倸 を調べ、その影響因子について検討してきた2,3)。その 結果、化学混和剤を使用しない場合の流動性は、粉体の 物理的性質と調合から求めた指標により評価することが できる可能性があることを示した。一方、化学混和剤を 用いた場合は、使用する粉体材料の種類や調合によって
化学混和剤の作用が異なり、その効果を考慮した指標の 検討が必要と考えた。

本研究では、普通ポルトランドセメント (以下 OPC) 抒 よび M-FA を使用したセメントペーストの流動性に及 ほすす化学混和剂の作用について検討するために、粉体材 料に対する化学混和剤の吸着性状や電気的反発力につい て検討し、セメントペーストの流動性との関係を調べた。

\section{2. 既往の研究}

これまでに、筆者らは OPC およびJIS I 種および II 種に適合する 2 種類の M-FA(以下それぞれ M-FA I 抒よび M-FA II) を用いたセメントペースト（以下 M-FA ペースト)の流動性について、三宅らが提案する 水膜厚粒径比 (平均余剩水膜厚 /固相材料の比表面積平 均粒径 $)^{4)}$ を指標とした検討を行った。検討においては、 ペースト中のセメント抢よび M-FA を固相、水を液相 としてセメントペーストの余剩水量㧍よび余剩水膜厚を 算出し、使用した粉体材料の平均粒径で除した值を水膜 厚粒径比 (以下余剩水膜厚粒径比、記号 $\delta_{\mathrm{w}} / \mathrm{d}$ ) とした。

化学混和剤を使用しないセメントペーストのフロー值 と $\delta_{\mathrm{w}} / \mathrm{d}$ の関係 ${ }^{3)}$ (以下 $\mathrm{f}-\delta_{\mathrm{w}} / \mathrm{d}$ 関係) を Fig. 1 に示す。

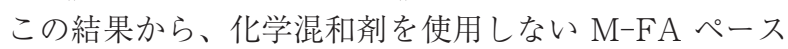
トの流動性は、粒子の凝集の影響を強く受ける小径粒子 を多く含む粉体を使用する場合を除き、余剩水膜厚粒径 比を指標として評価可能であると考えた。

化学混和剤としてポリカルボン酸系の高性能 $\mathrm{AE}$ 減 水剂(以下 $\mathrm{SP}$ ) を用いた場合の $\mathrm{f}-\delta_{\mathrm{w}} / \mathrm{d}$ 関係の一例 ${ }^{3)}$ Fig. 2 に示す。SPを使用した M-FA ペーストの流動 


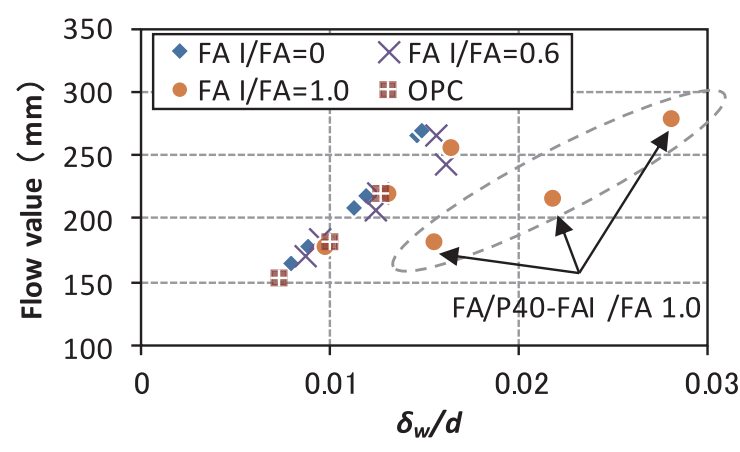

Fig. 1 Relationship between Flow Value and $\delta_{w} / d$ (SP : Non-use) $)^{3)}$

性と余㮃水膜厚粒径比の関係は、化学混和剤や M-FA I の使用量によって異なる関係を示し、それぞれの使用量 が多い場合に傾きが緩やかになることを確認した。この 結果は、SP のような化学混和剤を使用した高流動コン クリートは、余剰水膜厚粒径比のような粉体の物理的性 質を考慮した指標だけでなく、各粉体に対する化学混和 凨の作用機構を考慮することが必要であることを示して いるといえる。

セメントペースト、モルタルおよびコンクリート (以 下これらをまとめてセメント系混合物と称す)の流動性 に及ぼす SP の効果は、電気的反発力と立体障害効果に よるものと考えられている5)。電気的反発力の代表的な 理論としては DLVO 理論が挙げられる。DLVO 理論に よる 2 粒子間のポテンシャルエネルギー曲線は、斥力 ポテンシャルエネルギー $\left(\mathrm{V}_{\mathrm{R}}\right)$ と引力ポテンシャルエネ ルギー $\left(\mathrm{V}_{\mathrm{A}}\right)$ の和とされ、2 粒子間のポテンシャルエネ ルギーの極大值 (以下 $V_{\text {max }}$ ) が大きい值であるほど高い 流動性が得られると考えられている。また、この $\mathrm{V}_{\max }$ はゼー夕電位の絶対值と正の相関関係にあるとされてい

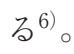

SP を使用したセメント系混合物は、ゼータ電位の絶 対值が $10 \mathrm{mV}$ 以下と小さいものの、電気的反発力によ り粒子を分散するタイプの化学混和剤を用いた場合と 同等以上の分散力を有する7)。これについて吉岡らは、 Napper らの提唱する分散理論に基ついて、立体障害効 果のポテンシャルエネルギーを算出し、SPを使用した 場合のセメント粒子分散効果は、電気的反発力よりも吸 着した分散剤の立体障害効果の影響が大きいことを示し ている ${ }^{7)}$ 。立体障害効果のポテンシャルエネルギーを算 出する式を式[1]に示すが、SP の立体障害効果のポテン シャルエネルギーは、粒子の単位面積あたりの SP 吸着 量 $(v$ : 単位面積あたりのグラフト鎖吸着数)の 2 乗に比 例していることがわかる。飯場らは、SP を用いたセメ ント系混合物の流動性について検討し、SP がセメント 粉末を分散させる作用は立体障害効果の寄与だけでなく 電気的反発力の効果も無視できないとしている

$$
\Delta V_{M}=(2 \pi)^{5 / 2} / 27\left(r^{2}\right)^{3 / 2} v^{2}\left(\alpha^{2}-1\right) a M k T
$$

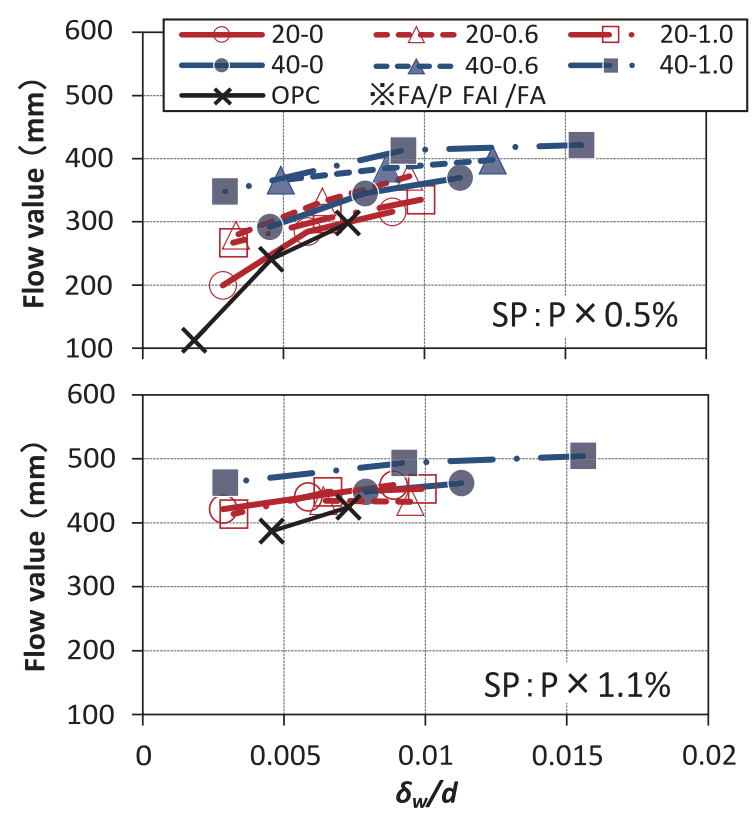

Fig. 2 Relationship between Flow Value and $\delta_{w} / d$ (SP : use) ${ }^{3)}$

$$
\begin{aligned}
\text { ここに、 } \Delta V_{M} & : \text { 立体障害効果ポテンシャルエネ } \\
& \text { ルギー } \\
a & : \text { 粒子半径 } \\
k & : \text { ボルツマン定数 } \\
\alpha & : \text { グラフト鎖の膨張係数 } \\
v & : \text { 単位面積あたりのグラフト鎖吸 } \\
& \text { 着数 } \\
r^{2}= & r_{0}^{2} \times \alpha^{2} \\
r_{0}{ }^{2} & : \text { 理想溶液中の差の二乗平均両端 } \\
& \text { 間距離 } \\
M & : \text { 吸着高分子セグメント密度分布 } \\
& \text { の粒子間距離 } \\
T & : \text { 絶対温度 }
\end{aligned}
$$

以上のことから、SPを使用した $\mathrm{M}-\mathrm{FA}$ ペーストの 流動性には、粉体の物理的特性と配合条件から定まる余 剰水膜厚粒径比、粉体材料への SP 吸着量および SP の 使用による電気的反発力の変化が影響していると考えら れる。そこで本研究では、M-FA ペーストにおける SP の吸着量およびゼー夕電位の測定を行い、前報3)で示し たフロー試験結果への影響について検討した。

\section{3. 実験概要}

\section{1 使用材料}

使用した粉体材料の化学・物理的性質を Table 1 に、 レーザー回析式粒度分布測定装置により測定した粉体材 料の粒度分布を Fig. 3 に示す。粉体材料は OPC および M-FA とした。M-FA は、風力粉砕・分級システムに よって分別した M-FA I および M-FA II を使用した。 化学混和剤は、高流動コンクリートなどに広く使用され ている SP を用いた。 


\section{2 混合粉体の特性}

各混合粉体の特性を Table 2 に、粒度分布を Fig. 4 に示す。 M-FA は全粉体体積に対する内割り置換とし、 FA/P は 20 \%および 40 \%とした。FA I/FA は質量比 とし、0、0.6 および 1.0 の 3 水準とした。なお、以 降ではFA/P と FA I/FA から定まる粉体を用いた水 準の名称は、Table 2 中の記号で表す(例えば $\mathrm{FA} / \mathrm{P}=$ $20 \%$ 、FA I/FA = 0.6 の場合は “20-0.6” と表記)。混 合粉体の特性としては、密度、比表面積、粒度分布捛よ び充填率を求めた。密度掞よび粒度分布については、各 粉体材料の測定結果とそれぞれの構成比率より算出した 值を用いた。比表面積について、ブレーン比表面積は、 既報 ${ }^{2)} に$ に拈いて実測值と混合比率を基に計算した值がほ ほ等しくなることを確認できたことから、各粉体材料の 比表面積と構成比率から算出した值を用いた。 BET 比 表面積は、混合粉体を用いて実際に測定した值である。 充填率は、タッピングによる充填率試験の結果である。 充填率試験は、事前に V 型混合機を用いて所定の比率 で混合した粉体を $250 \mathrm{ml}$ のメスシリンダー容器に入れ、 自動タッピング試験機により行った。タッピング回数

Table 1 Properties of Materials

\begin{tabular}{|c|c|c|}
\hline Material & Mark & Physical Properties \\
\hline Water & $\mathrm{W}$ & Tap Water \\
\hline Cement & OPC & $\begin{array}{l}\text { Ordinary Portland Cement } \\
\text { Density }: 3.16 \mathrm{~g} / \mathrm{cm}^{3} \\
\text { Average grain size }: 19.6 \mu \mathrm{m} \\
\text { Specific Surface Area (Blaine) }: 3240 \mathrm{~cm}^{2} / \mathrm{g} \\
\text { Specific Surface Area (BET) }: 0.91 \mathrm{~m}^{2} / \mathrm{g}\end{array}$ \\
\hline \multirow{2}{*}{$\mathrm{M}-\mathrm{FA}$} & $\begin{array}{c}\text { M-FA } \\
\text { I }\end{array}$ & $\begin{array}{l}\text { JIS A } 6201 \text { Type I } \\
\mathrm{SiO}_{2}: 66.1 \% \text {, Ig.loss }: 1.0 \% \\
\text { Density }: 2.39 \mathrm{~g} / \mathrm{cm}^{3} \\
\text { Average Particle Size }: 3.16 \mu \mathrm{m} \\
\text { Specific Surface Area (Blaine) }: 7820 \mathrm{~cm}^{2} / \mathrm{g} \\
\text { Specific Surface Area (BET) }: 1.80 \mathrm{~m}^{2} / \mathrm{g}\end{array}$ \\
\hline & $\begin{array}{c}\text { M-FA } \\
\text { II }\end{array}$ & $\begin{array}{l}\text { JIS A } 6201 \text { Type II } \\
\mathrm{SiO}_{2}: 68.3 \% \text {, Ig.loss : } 0.7 \% \\
\text { Density }: 2.16 \mathrm{~g} / \mathrm{cm}^{3} \\
\text { Average Particle Size : } 20.3 \mu \mathrm{m} \\
\text { Specific Surface Area (Blaine) }: 2760 \mathrm{~cm}^{2} / \mathrm{g} \\
\text { Specific Surface Area (BET) }: 0.86 \mathrm{~m}^{2} / \mathrm{g}\end{array}$ \\
\hline $\begin{array}{c}\text { Chemical } \\
\text { Admixture }\end{array}$ & SP & $\begin{array}{l}\text { Polycarboxylic Acid Based } \\
\text { Air-entraining and High-range Water-reducing } \\
\text { Admixture } \\
\text { Solid volume ratio : } 21 \%\end{array}$ \\
\hline
\end{tabular}

Table 2 Properties of Mixed Powder

\begin{tabular}{|c|c|c|c|c|c|c|c|}
\hline \multirow{2}{*}{$\begin{array}{l}\mathrm{FA} / \mathrm{P} \\
(\mathrm{vol} \% \%)\end{array}$} & \multirow{2}{*}{$\begin{array}{l}\text { FA I } \\
/ \text { FA }\end{array}$} & \multirow{2}{*}{ Mark } & \multirow{2}{*}{$\begin{array}{l}\text { Density } \\
\left(\mathrm{g} / \mathrm{cm}^{3}\right)\end{array}$} & \multicolumn{2}{|c|}{$\begin{array}{c}\text { Specific Surface } \\
\text { Area }\end{array}$} & \multirow{2}{*}{$\begin{array}{c}\text { Average } \\
\text { Particle } \\
\text { Size } D_{50} \\
(\mu \mathrm{m})\end{array}$} & \multirow{2}{*}{$\begin{array}{c}\text { Filling } \\
\text { Rate } \\
(\%)\end{array}$} \\
\hline & & & & $\begin{array}{l}\text { Blaine } \\
\left(\mathrm{cm}^{2} / \mathrm{g}\right)\end{array}$ & $\begin{array}{c}\mathrm{BET} \\
\left(\mathrm{m}^{2} / \mathrm{g}\right)\end{array}$ & & \\
\hline 0 & 0 & OPC & 3.16 & 3240 & 0.91 & 19.6 & 54.6 \\
\hline \multirow{3}{*}{20} & 0 & 20-0 & 2.95 & 3170 & 0.85 & 19.7 & 55.4 \\
\hline & 0.6 & $20-0.6$ & 2.98 & 3630 & 0.92 & 16.7 & 55.8 \\
\hline & 1.0 & $20-1.0$ & 3.01 & 3980 & 0.96 & 13.9 & 55.4 \\
\hline \multirow{3}{*}{40} & 0 & $40-0$ & 2.73 & 3090 & 0.77 & 19.8 & 56.6 \\
\hline & 0.6 & $40-0.6$ & 2.81 & 4070 & 0.95 & 13.1 & 56.5 \\
\hline & 1.0 & $40-1.0$ & 2.87 & 4790 & 1.05 & 6.20 & 53.9 \\
\hline
\end{tabular}

は、すべての混合粉体においてかさ容積が変化しなくな るように設定することとし、事前に行った試験の結果よ り 2000 回とした。タッピングの速さは、開始から 200 回までは試料の飛散等が生じないように 60 回/min と し、その後は 240 回/ $\mathrm{min}$ とした。粉体の充填率は、タッ ピング試験によって得られたかさ密度と、混合粉体の密 度から算出した。

\section{3 セメントペーストの調合}

実験は Table 2 に示すすべての粉体材料に対して行っ た。SP 吸着量およびゼー夕電位の測定に用いたセメン トペーストの調合を Table 3 掠よび Table 4 に示す。 また、フロー試験に使用したセメントペーストの調合を Table 5 に示す。各実験に扔ける SP 添加率を以下に示 すが、いずれも水の内割り置換とした。

$\mathrm{SP}$ 吸着量の測定は、水粉体質量比を 0.35 としたセ メントペーストを用いて行った。SPの添加量は、SP 吸着量に及ぼす SP 添加量の影響を確認するために、 $\mathrm{P}$ $\times 0.3 、 0.5$ 㧍よび $1.1 \%$ とした。

ゼー夕電位の測定は、水粉体容積比を 1.2 としたセ メントペーストを用いて行った。SP の添加量は、粉体 材料のゼー夕電位に及ぼす SP 添加量の影響を確認する ために、P×0、0.5 および $1.1 \%$ とした。

フロー試験に用いたセメントペーストの水粉体容積比

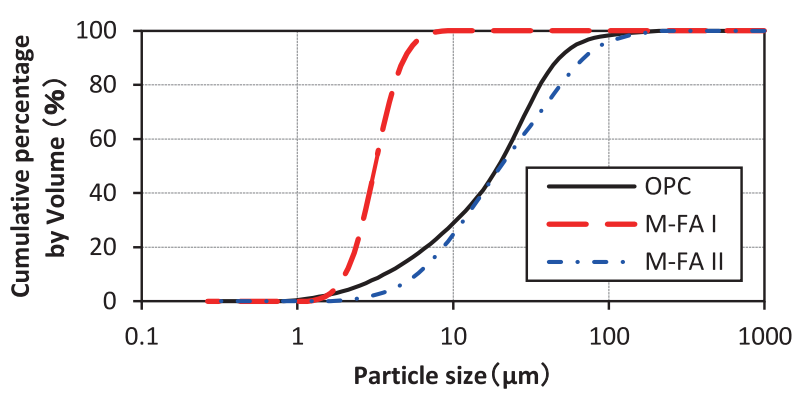

Fig. 3 Particle size of Powder
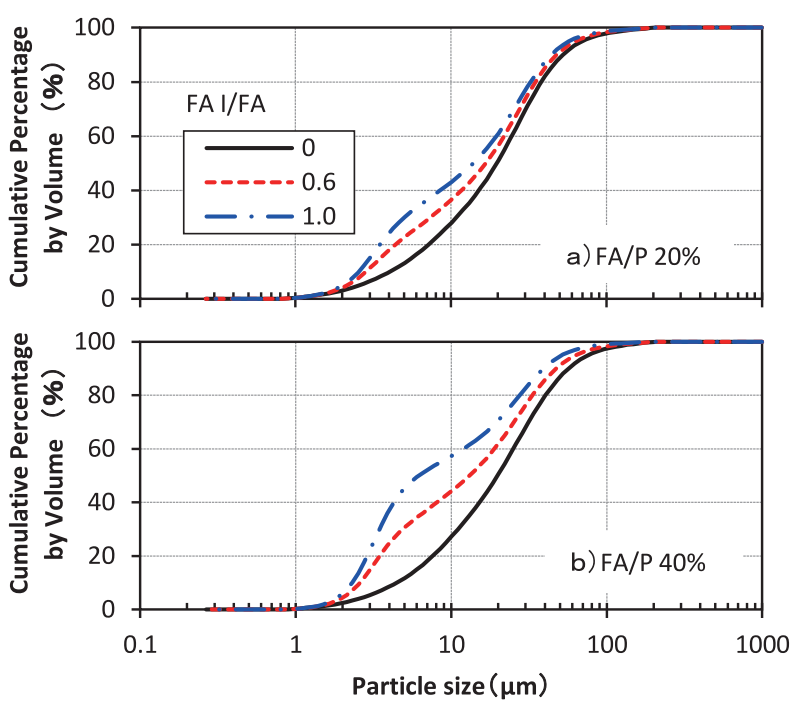

Fig. 4 Particle size of Mixed Powder 
Table 3 Mix Proportions (Amount of Adsorbed $\mathrm{C}_{\mathrm{SP}}$ )

\begin{tabular}{|c|c|c|c|c|}
\hline \multirow{2}{*}{} & \multicolumn{4}{|c|}{ Unit Contents (g/l) } \\
\cline { 2 - 5 } & $\mathrm{W}$ & OPC & M-FA I & M-FA II \\
\hline $20-0$ & 525 & 1500 & 0 & 0 \\
\hline $20-0.6$ & 511 & 1237 & 134 & 89 \\
\hline $20-1.0$ & 513 & 1232 & 233 & 0 \\
\hline $40-0$ & 491 & 964 & 0 & 439 \\
\hline $40-0.6$ & 496 & 955 & 278 & 184 \\
\hline $40-1.0$ & 500 & 949 & 478 & 0 \\
\hline
\end{tabular}

Table 5 Mix Proportions (Flow Value)

\begin{tabular}{|c|c|c|c|c|c|}
\hline & \multirow{2}{*}{$\mathrm{w} / \mathrm{p}$} & \multicolumn{4}{|c|}{ Unit contents $(\mathrm{g} / \mathrm{l})$} \\
\hline & & $\mathrm{W}$ & $\mathrm{OPC}$ & M-FA I & M-FA II \\
\hline \multirow{5}{*}{$\mathrm{OPC}$} & 0.9 & 474 & 1663 & 0 & \begin{tabular}{|l|}
0 \\
\end{tabular} \\
\hline & 1.0 & 500 & 1580 & 0 & 0 \\
\hline & 1.1 & 524 & 1505 & 0 & 0 \\
\hline & 1.2 & 545 & 1436 & 0 & 0 \\
\hline & 1.3 & 565 & 1374 & 0 & 0 \\
\hline \multirow{5}{*}{$20-0$} & 0.9 & 474 & 1331 & 0 & 220 \\
\hline & 1.0 & 500 & 1264 & 0 & 209 \\
\hline & 1.1 & 524 & 1204 & 0 & 199 \\
\hline & 1.2 & 545 & 1149 & 0 & 190 \\
\hline & 1.3 & 565 & 1099 & 0 & 182 \\
\hline \multirow{5}{*}{$20-0.6$} & 0.9 & 474 & 1331 & 144 & 96 \\
\hline & 1.0 & 500 & 1264 & 137 & 91 \\
\hline & 1.1 & 524 & 1204 & 130 & 87 \\
\hline & 1.2 & 545 & 1149 & 124 & 83 \\
\hline & 1.3 & 565 & 1099 & 119 & 79 \\
\hline \multirow{5}{*}{$20-1.0$} & 0.9 & 474 & 1331 & 256 & 0 \\
\hline & 1.0 & 500 & 1264 & 243 & 0 \\
\hline & 1.1 & 524 & 1204 & 231 & 0 \\
\hline & 1.2 & 545 & 1149 & 221 & 0 \\
\hline & 1.3 & 565 & 1099 & 211 & 0 \\
\hline \multirow{5}{*}{$40-0$} & 0.9 & 474 & 998 & 0 & 440 \\
\hline & 1.0 & 500 & 948 & 0 & 418 \\
\hline & 1.1 & 524 & 903 & 0 & 398 \\
\hline & 1.2 & 545 & 862 & 0 & 380 \\
\hline & 1.3 & 565 & 824 & 0 & 363 \\
\hline \multirow{5}{*}{$40-0.6$} & 0.9 & 474 & 998 & 288 & 192 \\
\hline & 1.0 & 500 & 948 & 274 & 183 \\
\hline & 1.1 & 524 & 903 & 261 & 174 \\
\hline & 1.2 & 545 & 862 & 249 & 166 \\
\hline & 1.3 & 565 & 824 & 238 & 159 \\
\hline \multirow{5}{*}{$40-1.0$} & 0.9 & 474 & 998 & 512 & 0 \\
\hline & 1.0 & 500 & 948 & 486 & 0 \\
\hline & 1.1 & 524 & 903 & 463 & 0 \\
\hline & 1.2 & 545 & 862 & 442 & 0 \\
\hline & 1.3 & 565 & 824 & 423 & 0 \\
\hline
\end{tabular}

は、前報 ${ }^{3)}$ で示したように0.9〜1.3とした。SP 添加量 は P $\times 0.3 \% 、 0.5 \%$ および $1.1 \%$ とした。

\section{4 試料の調整および試験方法}

(1) SP の吸着量

a) 試料の調製

セメントペーストは、粉体材料に練混ぜ水を加えて 3
Table 4 Mix Proportions ( $\zeta$ potential)

\begin{tabular}{|c|c|c|c|c|}
\hline \multirow{2}{*}{ OPC } & \multicolumn{4}{|c|}{ Unit Contents (g/l) } \\
\cline { 2 - 5 } & $\mathrm{W}$ & OPC & M-FA I & M-FA II \\
\hline $20-0$ & 545 & 1436 & 0 & 0 \\
\hline $20-0.6$ & 546 & 1152 & 0 & 191 \\
\hline $20-1.0$ & 545 & 1150 & 125 & 83 \\
\hline $40-0$ & 549 & 867 & 221 & 0 \\
\hline $40-0.6$ & 546 & 863 & 249 & 382 \\
\hline $40-1.0$ & 544 & 859 & 440 & 0 \\
\hline
\end{tabular}

分間練り混ぜ、注水後 10 分経過した時点で試料を遠心 分離し、上澄みをろ過して、ろ液を採取した。採取した ろ液は試料の炭酸化を抑制するために速やかに塩酸溶液 で酸性に調製した。

b) 全有機体炭素(TOC) 濃度の測定条件

本研究では、全有機体炭素計 (TOC 計)により、ろ液 中に含まれる有機体炭素濃度の測定を行った。有機体炭 素濃度の測定条件は、注水量は $50 \mu \mathrm{m}$ 、酸添加量を $1.5 \%$ 、 通気時間を 1.5 分とした。

c) SP 吸着量の算出方法

SP の吸着量は、粉体に吸着した SP の分散成分に含 まれる炭素量を測定した。吸着した炭素量の測定はろ 液中に含まれる全有機体炭素量 (以下液相 TOC 濃度) を測定し、SP 自体の炭素含有量と SP 添加量からセメ ントペースト中の SP 由来の全炭素量を求め、この值か ら採取したろ液の液相 TOC 濃度と SP 無添加時の液相 TOC 濃度を差し引き、その值を粉体 $1 \mathrm{~g}$ に対して吸着 した炭素量として求め、粉体の表面積あたりの吸着量を 算出して評価を行った。なお、本研究では SP 由来の炭 素と未燃カーボンなどその他の炭素と区別するために、 以降では $\mathrm{SP}$ 由来の炭素を $\mathrm{C}_{\mathrm{SP}}$ と表記し、粉体の表面積 あたりの吸着量を $\mathrm{C}_{\mathrm{SP}}$ 吸着量とする。

(2) ゼー夕電位

a）粉体材料の調製

ゼー夕電位の測定に使用する粉体材料は、事前にそれ ぞれの調合比率で混合して使用した。粉体の混合は、各 粉体材料を所定量計量し、ポリ袋内で 3 分間エアブレ ンディングして均一化した。

b) M-FA ペーストの作製

混合した試料は、あらかじめ所定量に計量したイオン 交換水中に、金属製のさじで攪汼しながら 5 回に分け て 2.5 分間で投入した。また、試料投入後は、さらに 2.5 分間の手練りを行い、ゼー夕電位の測定に供した。

c）ゼー夕電位および $\mathrm{pH}$ の測定

ゼー夕電位の測定は超音波方式で行った。 $\mathrm{pH}$ の測定 はガラス電極法により行った。ゼータ電位および $\mathrm{pH} の$ 測定は、作製したペースト中にゼータ電位測定用のプ ローブ(測定子)と $\mathrm{pH}$ 電極を挿入して測定した。測定 は、注水時から起算して約 10 分後から開始し、連続的 に 10 分間で合計 6 回測定し、平均值を求めた。 


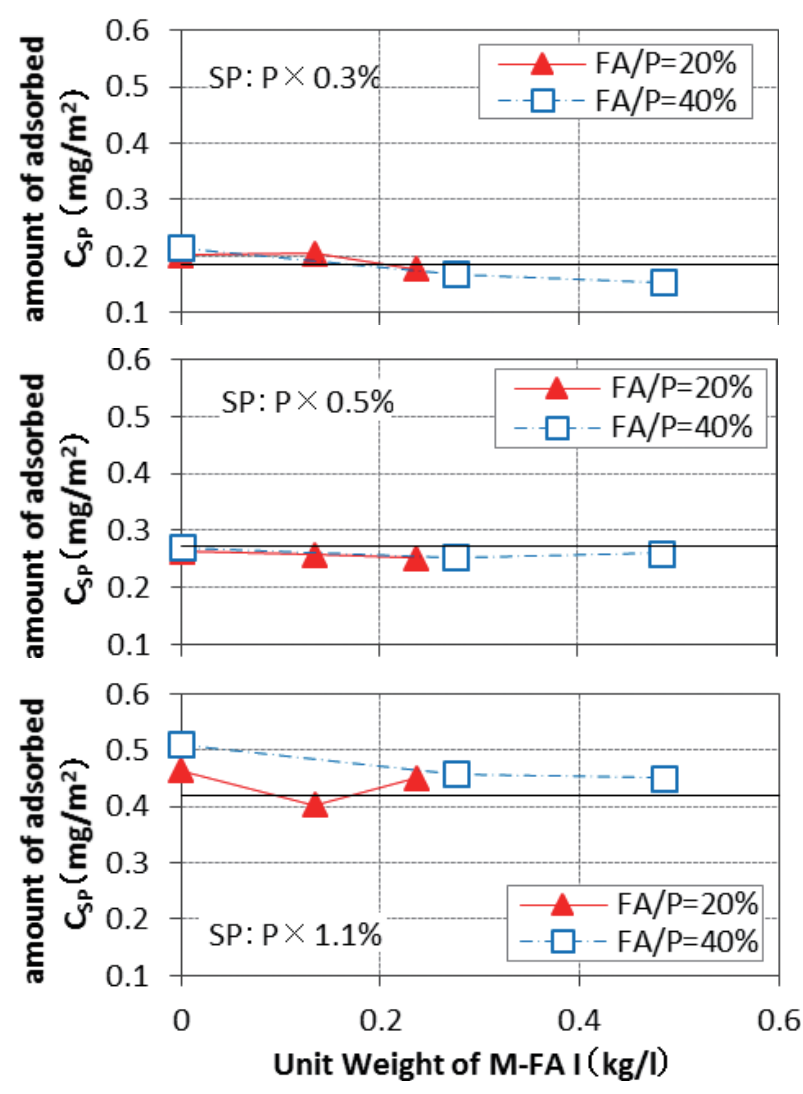

Fig. 5 Amount of adsorbed $\mathrm{C}_{\mathrm{SP}}$ per Surface Area by BET method
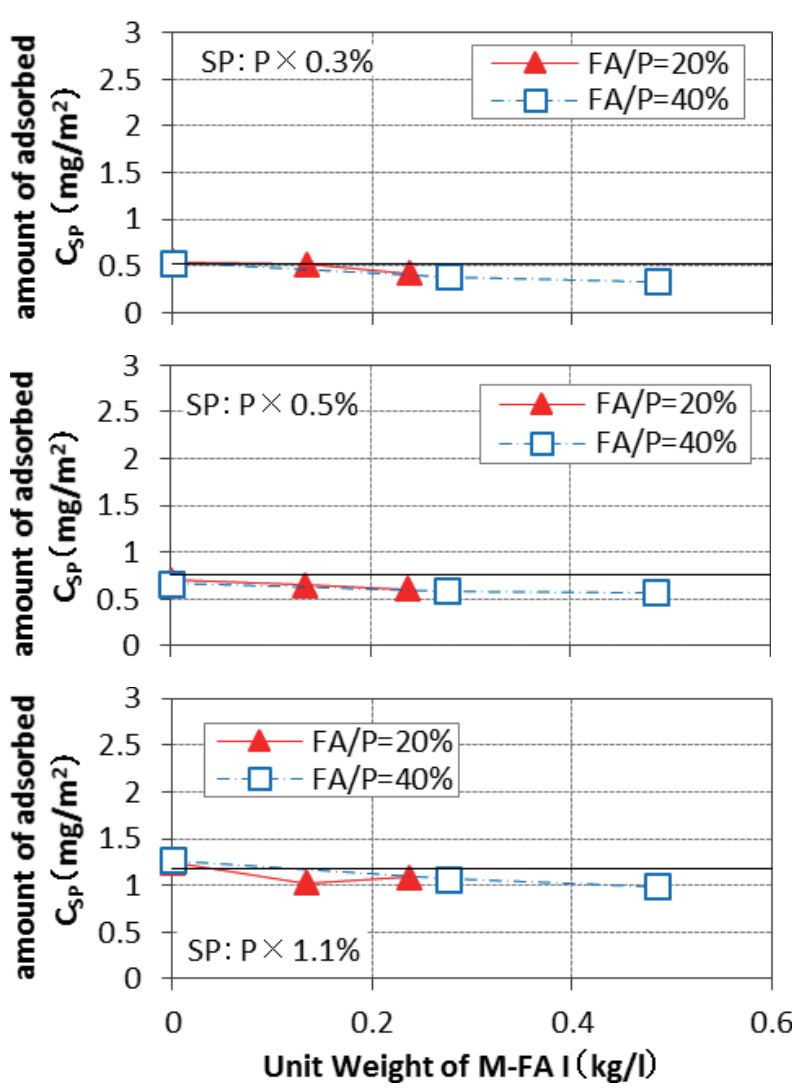

Fig. 6 Amount of adsorbed $\mathrm{C}_{\mathrm{SP}}$ per Surface Area by Blaine method

いては、BET 比表面積およびブレーン比表面積を用い て算出したいずれの場合も評価可能と考えられるが、以 降では太田らの研究 ${ }^{10)}$ と同様に、ブレーン比表面積を 用いて算出した $\mathrm{C}_{\mathrm{SP}}$ 吸着量の結果について述べる。

$\mathrm{C}_{\mathrm{SP}}$ 吸着量は $\mathrm{SP}$ 添加率が大きくなるほど多く、FA/P や M-FA I 量による差は明確に認められなかった。

既往の研究において、 $\mathrm{C}_{\mathrm{SP}}$ 吸着量は粉体の種類ごとに 一定となることが示されている ${ }^{10)}$ が、本研究の範囲では、 粉体材料の種類およびその混合割合によらず、SP 添加 率ごとに $\mathrm{C}_{\mathrm{SP}}$ 吸着量が一定の值となると考えた。

（2）混合粉体を用いたセメントペーストの流動性に及ぼ す高性能 $\mathrm{AE}$ 減水剂の吸着量の影響

これまでの検討結果より、M-FA I 量が多い水準で は、 $\delta_{w} / d$ が小さい場合でも SP の使用による流動性の 増大効果が大きいことが明らかになっている3）。前述の 立体障害効果の計算式によると、立体障害効果には単位 面積あたりの SP 吸着量の 2 乗が影響しており、その 值が大きいほど立体障害効果が大きいと考えることがで きる ${ }^{6)}$ 。しかし、本研究では、粉体材料の種類およびそ の混合割合によらず、 $\mathrm{SP}$ 添加率ごとに $\mathrm{C}_{\mathrm{SP}}$ 吸着量は一 定の值になると考えられた。このことから前述の結果に おいては立体障害効果の影響は小さいと考えた。

石らは、ガラス質の微粉末は、減水剤の使用による 粉末の分散効果が大きく、微粉末の鉱物組成がセメント 系混合物の流動性に影響を及ぼす可能性を示唆してい 

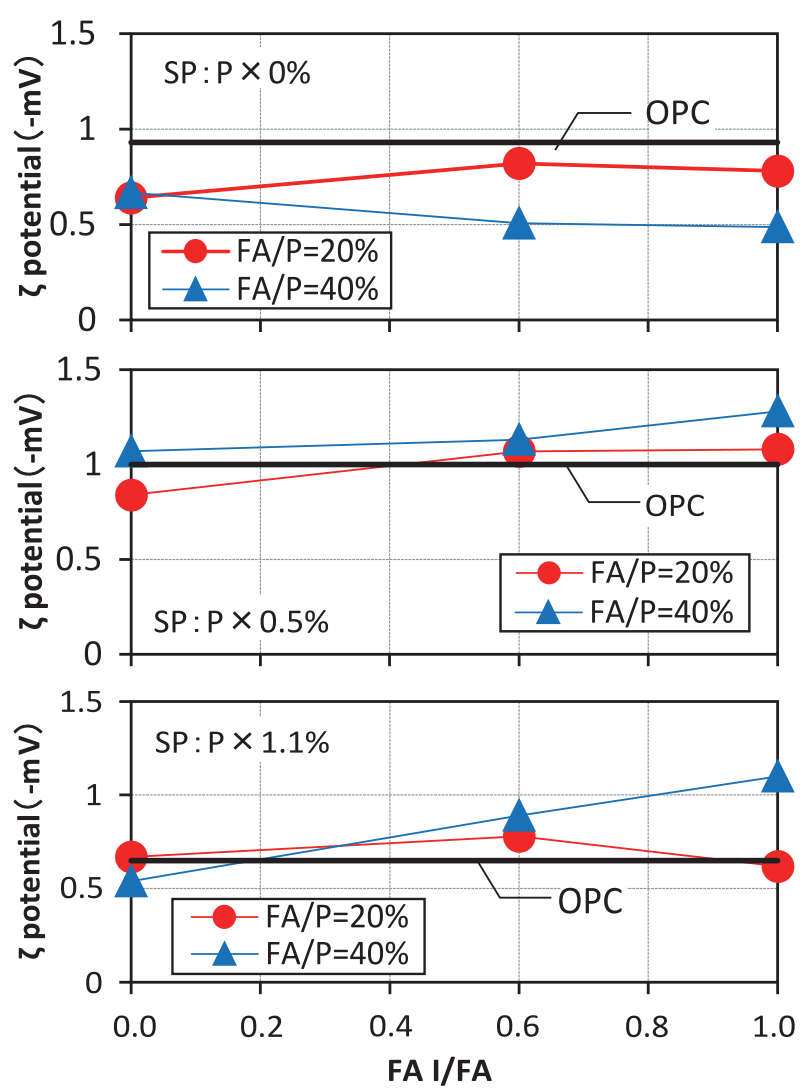

Fig. 7 Relationship between $\zeta$ Potential and FA I/FA

る11)。フライアッシュにおいては、45〜85 \%がガラス質 であるため ${ }^{12)}$ 、使用するフライアッシュの種類によって 減水剂の使用による粉末の分散効果は変化する可能性が あると考えた。また、名和らはセメント粒子の凝集に及 ぼす粒子径の影響について、表面電位の絶対值が小さい 場合には粗粒子が凝集を促進することを示している ${ }^{13)}$ 。 そこで、M-FA を用いたセメントペーストのゼータ電 位を測定し、粉末の分散効果への影響について調べた。

4. $2 \mathrm{M}-\mathrm{FA}$ を用いたセメントペーストのゼータ電位測 定結果

ゼータ電位と FA I/FA の関係を Fig. 7 に示す。SP 未使用の場合における M-FA ペーストのゼー夕電位 の絶対值は、FA/P が $20 \%$ および $40 \%$ の場合ともに $\mathrm{OPC}$ よりも小さく、FA I/FA の違いによる差が小さい。 しかし、FA/P が 40 \%ではFA I/FA が大きい場合に ゼー夕電位の絶対值がわずかに小さくなった。これまで に 40-0.6 や 40-1.0のような平均粒径が小さい混合粉 体を使用した M-FA ペーストでは、粒子の凝集が生じ る可能性があることを示しているが2,3)、この結果はこ れらのことと関係している可能性がある。

SPを使用した M-FA ペーストのゼータ電位の絶対 值について、SP 添加率が $\mathrm{P} \times 0.5 \%$ の場合は、FA/P が $20 \%$ および $40 \%$ ともにFA I/FA が大きいほど緩 やかに大きくなった。また、これらの值を OPC と比 較すると、40-1.0 では OPC よりも大きく、その他の 水準では $\mathrm{OPC}$ と同程度であった。 $\mathrm{SP}$ 添加率が $1.1 \%$
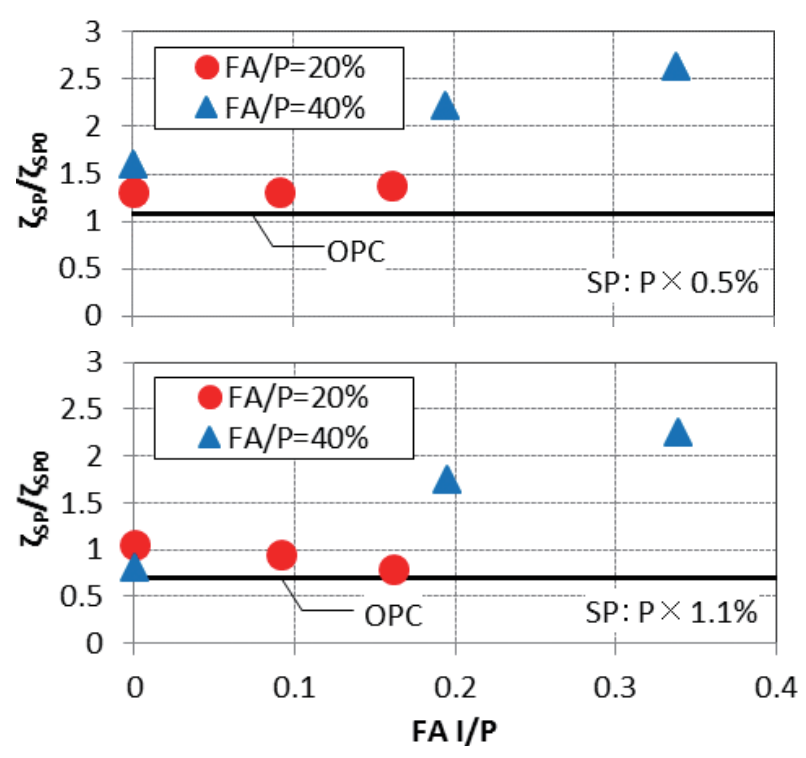

Fig. 8 Relationship between $\zeta_{\mathrm{SP}} / \zeta_{\mathrm{SP} 0}$ and FA I/P

の場合は、FA/P が $20 \%$ ではFA I/FAによる差は 認められず、いずれも OPC と同程度であった。一方、 FA/P が 40 \%では FA I/FA が大きいほど大きく、400.6 および 40-1.0 では OPC よりも大きくなった。

これらの結果より、M-FA I の使用量が多い場合は、 $\mathrm{SP}$ の添加による M-FA ペーストのゼータ電位の変化 が大きいと考えられる。SP未使用時のゼー夕電位の絶 対值に対する SP 使用時のゼー夕電位の絶対值の比(以 下 $\zeta_{\mathrm{SP}} / \zeta_{\mathrm{SP} 0}$ ) と全粉体量に対する M-FA I の質量比(以下 FA I/P)の関係を Fig. 8 に示すが、この図からも FA $\mathrm{I} / \mathrm{P}$ が大きい場合に $\zeta_{\mathrm{SP}} / \zeta_{\mathrm{SP} 0}$ が大きいことがわかる。

以上のように、物理・化学的性質が異なる 2 種類の $\mathrm{M}-\mathrm{FA}$ と OPC を使用した M-FA ペーストのゼータ電 位は、調合によって SP 添加によるその変動比が異なり、 本研究では M-FA I を多く使用することによってその 変動が大きくなることを確認した。

4. 3 M-FA に用いたセメントペーストの流動性評価指 標に関する検討

本研究では、M-FA ペーストの流動性および M-FA ペースト中の粉体材料に及ぼす SP の効果を検討するた めに、粉体材料に対する化学混和剂の吸着性状やゼー 夕電位について検討した。SP の立体障害効果は、粒子 表面に吸着している高性能 $\mathrm{AE}$ 減水剂の量と吸着膜厚 に依存すると考えられている6,14)。本研究では 1 種類 の $\mathrm{SP}$ を使用しており、混合粉体の $\mathrm{C}_{\mathrm{SP}}$ 吸着量は、粉 体材料の種類や調合条件に関わらず SP 添加率ごとに一 定の值となった。このことから、SP 添加率が一定の場 合における SP の立体障害効果は、粉体材料の種類およ びその混合割合に関わらず一定であったと仮定した。ま た、一般にポリカルボン酸系の混和剤を使用した場合の セメント系混合物の流動性には、電気的反発力の影響は 小さいと考えられている7)。本研究でも、SP を使用し た M-FA ペーストのゼータ電位は小さい值であり、電 


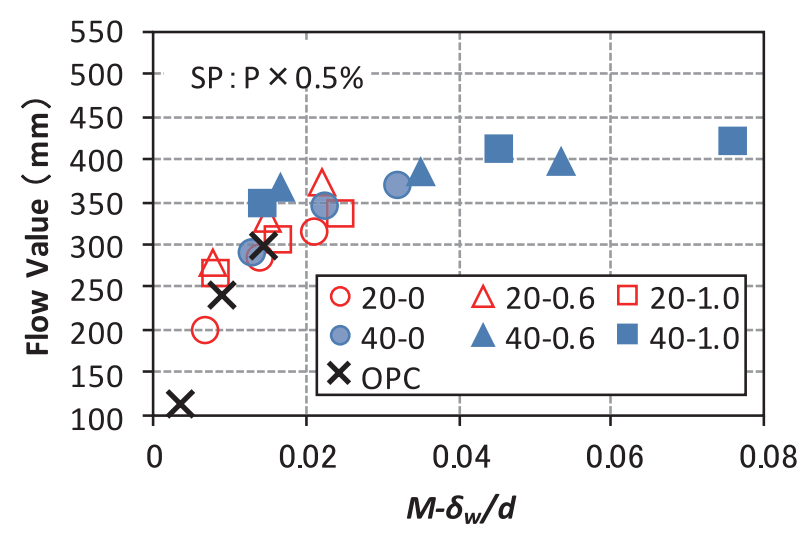

Fig. 9 Relationship between Flow Value and $\mathrm{M}-\delta_{w} / d$ (SP : $\mathrm{P} \times 0.5 \%$ )

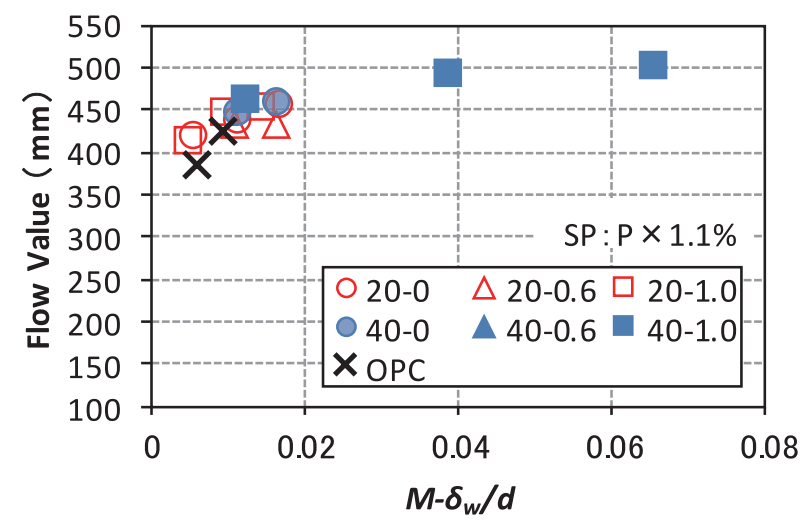

Fig. 10 Relationship between Flow Value and $\mathrm{M}-\delta_{w} / d$ (SP : $\mathrm{P} \times 1.1 \%$ )

気的反発力による粉体分散効果は小さいものと考えられ る。しかし、使用した粉体材料㧍よびその調合によって、 $\mathrm{SP}$ 添加によるゼー夕電位の変動比 $\left(\zeta_{\mathrm{SP}} / \zeta_{\mathrm{SPO}}\right)$ が異なっ た。現段階においてこの原因は明らかになっていない が、使用した粉体材料の鉱物組成や粉末度の違いによっ て、SP の粉体分散効果が異なる可能性があると考えた。 これまでの検討結果を踏まえて、M-FA ペーストの 流動性に及ぼす評価指標について検討した。評価指標の 検討では、ペースト中に扔ける粉体粒子の凝集が懸念さ れる。筆者らも細かい粒子を使用した場合に余剩水膜厚 粒子径比に対するペーストの流動性が小さくなることを 確認し、その原因として粉体の凝集が影響を及ぼしてい る可能性を指摘した ${ }^{2)}$ 。しかし、本研究に扔いて SP 使用した場合では、細かい粒子を使用した場合の流動性 は高く、ゼー夕電位の絶対值も大きくなる結果が得られ ている。これは SP の粉体分散効果によって、粉体の凝 集を抑制したことによる考えた。そこで、本研究で対象 としたセメントペーストに拈いては、SPを使用するこ とで粉体が完全に分散したと仮定して検討した。

これまでの結果より、SPを使用した $\mathrm{M}-\mathrm{FA}$ ペース トの流動性には、余剩水膜厚粒径比 $\left(\delta_{w} / d\right)$ と SP 添加に よるゼー夕電位の変動比 $\left(\zeta_{\mathrm{SP}} / \zeta_{\mathrm{SP}}\right)$ が影響を及ぼしてい ると考えた。ゼー夕電位の絶対值は SP の添加によって
大きくなり、その増大比に応じて見かけの余剩水膜厚粒 径比が大きくなり、流動性が向上した可能性があると考 えた。そこで、これらを乗じた值を評価指標 (以下 $\mathrm{M}$ $\left.\delta_{w} / d\right)$ として、M-FA ペーストの流動性との関係を $\mathrm{SP}$ 添加率ごとに確認した。結果を Fig. 9 および Fig. 10 に 示す。 $\mathrm{M}-\mathrm{FA}$ ペーストのフロー值と $\mathrm{M}-\delta_{w} / d$ の関倸は、 $\mathrm{SP}$ 添加量ごとに一つの曲線で表すことができた。以上 の結果より、SP を使用した場合に扔いては、粉体が完 全に分散したと仮定した条件に执いて、流動性評価を行 うことは概ね可能であると考えた。

\section{5. まとめ}

本研究では、M-FAの高流動コンクリートへの適用 に向けた検討の一環として、M-FA ペーストの流動性 に及ほす化学混和剂の効果を検討するために、粉体材料 に対する化学混和剂の吸着性状やゼー夕電位について検 討し、M-FA ペーストの流動性との関係を調べた。そ の結果、以下の知見が得られた。

1） M-FAペーストの粉体表面積あたりのSP吸着量は、 使用した粉体材料の種類およびその混合割合に関わ らず一定であった。

2） M-FAIの使用量が多い M-FAペーストは、SP の使用によるゼー夕電位の変化が大きくなった。

3） M-FA ペーストの流動性は、余剩水膜厚粒径比打 よび SP 添加によるゼー夕電位の変動比を乗じた值 との関係と一つの曲線で表すことができる。

\section{謝辞：}

本研究を実施するにあたり株式会社太平洋コンサル夕 ントに多大なご協力を頂きました。ここに記して感謝の 意を表します。

\section{参考文献：}

1）佐藤嘉昭、大分大学コンクリート工学研究室：高品 質フライアッシュ (CfFA)の可能性を探るーコンク リート構造物の長寿命化に向けて、セメント・コン クリート、No. 777、pp. 2-12 (2012)

2）石田征男ほか：加熱改質フライアッシュを用いたセ メントペースト抢よびモルタルのコンシステンシー とその評価指標に関する研究、コンクリート工学年 次論文報告集、Vol. 38、No. 1、pp. 1323-1328（2016）

3）石田征男ほか：加熱改質フライアッシュを用いたセ メントペーストの流動性に関する研究、セメント . コンクリート論文集、Vol. 70、pp. 313-320（2016）

4）三宅淳一、松下博通、取違剛：余剩水膜によるモル タル㧍よびコンクリートのコンシステンシーの評価 に関する研究、土木学会論文集 E、No. 62、No. 2、 pp. 306-319 (2006)

5）田中義夫、太田晃: 高性能 $\mathrm{AE}$ 減水剤の化学構造 と作用機構、エヌエムビー研究所報、No. 9、pp. 511 (1992) 
6）菅俣匠、太田晃：100 150N/ $\mathrm{mm}^{2}$ 級超高強度コ ンクリート用高性能 $\mathrm{AE}$ 減水剂の動向、材料、 Vol. 54、No. 8、pp. 794-803 (2005)

7）吉岡一弘ほか：セメント粒子の分散に及ぼす高性能 減水剂の立体障害効果の役割、コンクリート工学年 次論文報告集、Vol. 16、No. 1、pp. 335-340（1996）

8）飯場栄二ほか：ポリカルボン酸系分散剂の化学構造 が流動性に及ぼす影響、コンクリート工学年次論文 集、Vol. 22、No. 2、pp. 151-156（2000）

9）相良健一、魚本健人：使用材料の粒度分布が高流動 コンクリートのフレッシュ時の品質に及ぼす影響、 コンクリート工学年次論文報告集、Vol. 19、No. 1、 pp. 31-36 (1997)

10）太田晃、魚本健人：高性能 $\mathrm{AE}$ 減水剂の化学構造 と流動作用効果の基礎的研究 その (2) 各種結合材粒 子に対するポリカルボン酸系分散剤の分散効果、生
産研究、50 巻、9 号、pp. 40-43（1998）

11）石雲興、松井勇、谷川恭雄：フレッシュコンクリー トの流動性に及ぼす各種微粉末の影響に関する実験 的研究、コンクリート工学論文集、第 13 巻、第 3 号、 pp. 11-18 (2002)

12）土木学会：コンクリートライブラリー 132、循環型 社会に適合したフライアッシュコンクリートの最 新利用技術一利用拡大に向けた設計施工指針試案一、 p. 113 (2009)

13）名和豊春、江口仁、大久保正弘：セメントペースト およびモルタルの流動性に及ぼすセメントの粉末度 および粒度分布の影響、土木学会論文集、No. 433、 V-15、pp. 139-147（1991）

14）菅俣匠ほか：練混ぜ時における高性能 $\mathrm{AE}$ 減水剂 の粒子分散効果に関する定量的評価、土木学会論文 集、No. 634、V-45、pp. 255-267（1999）

\title{
STUDY ON EFFECT OF CHEMICAL ADMIXTURE ON FLUIDITY OF CEMENT PASTE CONTAINING CARBON-FREE FLY ASH
}

\author{
Masao ISHIDA ${ }^{* 1}$, Yoshiaki SATO ${ }^{* 2}$, Toshihiro OTANI*3 and Kenji UEDA ${ }^{* 2}$ \\ *1 OITA UNIVERSITY, Graduate Student, Doctors Course of Environmental Engineering (700, \\ Dannoharu, Oita-shi, Oita 870-1192, Japan) \\ TAIHEIYO CEMENT CORPORATION \\ *2 ZEROTECHNO Co., Ltd. (1-5-16, Suehiro-machi, Oita-shi, Oita 870-0027, Japan) \\ *3 OITA UNIVERSITY, Division of Architecture, Department of Innovative Engineering Faculty \\ of Science and Technology (700, Dannoharu, Oita-shi, Oita 870-1192, Japan)
}

\begin{abstract}
The purpose of this study is to clarify the influence of the characteristics of carbon free fly ash (M-FA) on the fluidity of high fluidity concrete, the adsorption quantity of polycarboxylic acid based Air-entraining high range water reducing admixture (SP) to the cement paste containing M-FA was investigated. Two types of M-FA, JIS class I (M-FAI) and II (M-FAII), were used. The mix proportions of the cement paste was changed the replacement of $\mathrm{M}-\mathrm{FA}$ and the percentage of M-FAI. And the zeta potential of various mix proportion of these powders were measured. As a results, regardless of the type of powder materials and mix proportions, the amount of adsorbed SP per unit mass of powder increased, but the amount of adsorbed SP per powder surface area were constant. And in case of using SP, the larger the percentage of M-FAI, the higher the zeta potential. Therefore, it seemed that the fluidity of cement paste containing M-FA is affected not only by the physical properties of powder but also by the change in the surface potential. And it is possible to evaluate the fluidity of M-FA paste by using the index using the excess water film thickness particle diameter ratio and the variation ratio of zeta potential.
\end{abstract}

KEY WORDS : Carbon-free Fly Ash, Specific Surface Area, Air-entraining and high-range waterreducing admixture, Cement paste, Fluidity, Excess water film theory, Amount of adsorbed polymer, Zeta Potential 